\title{
Impact through participatory research approaches: an archetype analysis
}

\author{
Theresa Tribaldos $^{1,2}$, Christoph Oberlack ${ }^{1,2}$ and Flurina Schneider ${ }^{1,2}$
}

\begin{abstract}
Participatory research approaches are often assumed to be effective for addressing sustainability problems that involve a substantial amount of complexity, uncertainty, and conflicting values. The adaptive and integrative character of these approaches engages various scientific and nonscientific actors in collective knowledge production processes. An increasing number of case studies documents pathways to impact triggered by participatory research approaches. However, cumulative learning across cases about the impacts of participatory research projects remains limited to date. One question is of particular interest, namely how and when different intensities of actor interactions in participatory research effectively contribute to advancing sustainable development.
\end{abstract}

In this paper we address this knowledge gap by presenting a meta-analysis of 29 case studies of participatory research projects in agricultural settings. The study protocol follows systematic case retrieval and selection, coding, and data analysis through formal concept analysis. We introduce and utilize a new diagnostic framework to analyze the links between the intensity of actor interactions, sustainability impact goals, context conditions, and sustainability impacts. The results show that three archetypical patterns describe how the 29 case studies report that participatory research projects generate sustainability impacts: learning, knowledge products, and real-world transformations. Impact in all three patterns is consistently associated with higher intensities of interactions, i.e., coproduction and less consultation but not mere information. The most frequently reported impact is learning in a context of resources and environment problems. In this configuration, coproduction of knowledge is mainly used during the second research phase. However, the results also show that coproduction in the final phase of a participatory research project is more often used to achieve the impact of real-world transformations, which presumably involves more complexity and contestation than other impacts. We conclude that participatory research projects, which aim at transformative impacts in complex settings beyond knowledge products and learning, need to sustain high intensities of actor interactions in knowledge coproduction throughout all research phases to achieve their sustainability impact goals.

Key Words: archetype analysis; archetypical configurations; diagnostic framework; participatory research approaches; sustainability problems

\section{INTRODUCTION}

Research that aims to support sustainability transformations has been challenged by the wickedness of sustainability problems in social-ecological systems (Folke et al. 2005, Termeer et al. 2013). Wickedness includes substantial amounts of complexity (Ostrom 2009), uncertainty (Pahl-Wostl et al. 2007), and normativity (Leach et al. 2010). Exclusively academic approaches to these problems often fail to significantly contribute to sustainability transformations (Pahl-Wostl 2002, Huutoniemi 2014). Hence, participatory research approaches are increasingly used in sustainability research, based on the expectation that they are socially robust and comprehensively involve scientific and societal actors in knowledge codesign and coproduction (Lang et al. 2012, Polk 2014, Moser 2016, Schneider and Buser 2018). They aim to address societally relevant questions, deliver results that are based on multiple sources of expertise, and take different actors' perspectives and values into account. Hence, their implementation is considered to be more likely and they are meant to produce salient, credible, and legitimate results (Cash et al. 2002). However, involving societal actors in the scientific knowledge production process does not per se lead to societal impact (Reed 2008, Kaufmann-Hayoz et al. 2016).

Consequently, literature increasingly focuses on impacts of participatory research, and scholars have started to conceptually define societal impact (Godin and Dore 2005, Bornmann 2013, Miettinen et al. 2015). Since about 1990, a broad variety of frameworks have been developed to illustrate how impact can take place. Among the more popular models we find the payback model of Buxton and Hanney (1996) and the ESRC model (ESRC 2011). These models usually consist of a series of stages such as inputs, research processes, direct outputs, and further outcomes and impacts, which are connected over various feedback loops. The terminology of stages is, however, heterogeneous. Whereas some studies treat shifts in peoples' perspectives as direct outcomes of participatory processes, others consider them as further impacts due to larger political debates. Recently, sustainability researchers have begun to apply and further develop such frameworks (Walter et al. 2007, Wiek et al. 2014, Mitchell et al. 2015, Luederitz et al. 2017). Walter et al. (2007) focus on product and process-related effects in terms of decision-making capacities. Wiek et al. (2014) emphasize research events, the quality of participation in the research process, and appropriate means for addressing actors' needs. Mitchell et al. (2015) proceed from desired outcomes such as improving a situation, contributing to the knowledge base and distribution, or transformational learning and what activities these entail. Luederitz et al. (2017) provide an evaluation framework with thematic questions about outputs, outcomes, processes, and inputs. Other scholars, however, question the usefulness of such linear approaches and highlight the existence of multiple pathways to impact (Polk 2014, Bergmann et al. 2017, Newig et al. 2018, Muhonen et al. 2020).

So far, impact frameworks have mostly been applied to individual cases with some notable exceptions of comparative analyses of

${ }^{1}$ Centre for Development and Environment (CDE), University of Bern, Bern, Switzerland, ${ }^{2}$ Institute of Geography, University of Bern, Bern, Switzerland 
larger samples (de Jong et al. 2016, Schneider and Buser 2018, Zscheischler et al. 2018, Herrero et al. 2019, Newig et al. 2019). Although de Jong et al. (2016) find that societal actor involvement in research funding programs improves societal impact, they do not find a correlation for societal actor involvement and impact in research projects. Herrero et al. (2019) and Newig et al. (2019) point to the importance of an early involvement of societal actors for impact generation and social learning, and Schneider and Buser (2018) analyze different intensities of actor interactions in different contexts. Zscheischler et al. (2018) present a success profile of transdisciplinary research, which includes mutual learning, science-practice cooperation on equal footing, and the synthesis of results.

Other evidence for sustainability impacts of participatory research mainly relies on individual case studies in particular social-ecological contexts (e.g., Oettlé et al. 2004, Termeer and Kessener 2007, Akpo et al. 2015) but cumulative learning across cases remains limited. Identified impacts of participatory research include the spread of usable products, enhanced capacity, network effects, and structural changes in decision making, public discourses, economic benefits, or changes in institutions and behavior (e.g., Walter et al. 2007, Schneider et al. 2009, Wiek et al. 2014, Kaufmann-Hayoz et al. 2016, Luederitz et al. 2017). However, findings also suggest that socially robust knowledge does not per se contribute to further impact (Polk 2014), and that stakeholder empowerment is often insufficient (Brandt et al. 2013). Indeed, Schneider et al. (2009) emphasize the importance of an atmosphere of trust, truly acknowledging different actors' perspectives and the possibility to create implicit and explicit knowledge. Blackstock et al. (2007) stress that adapted practices need supportive governance mechanisms, and Newig et al. (2018) identify conditioning factors such as trust, structured knowledgeintegration-processes, or capacity building of participants for better outcomes in environmental decision making. Schneider and Buser (2018) find that the intensity of actor interactions need to differ with the level of contestation, actor diversity, actor interest, and existing collaborations. Moreover, they stress that the envisaged sustainability contribution highly influences the choice of participatory methods. Consequently, the question if and how participatory approaches can reach societal impact depends on several aspects including context factors and the strived for sustainability goals.

In this paper, we aim to learn from the contextualized but scattered findings published as individual case studies and to study the patterns between different intensities of actor interactions and impacts while considering different contexts and sustainability goals. We start from the premise that different intensities of actor interactions and the timing of these interactions are important for generating impact under different context conditions and sustainability goals. Our guiding research questions are the following: What are the main self-reported sustainability impacts of participatory research projects, and how do the projects generate these impacts? How and when do different intensities of actor interactions contribute to the reported impacts? We particularly focus on the role of contexts and sustainability goals in these patterns.

To address our research questions, we followed a two-step approach: first, we developed our diagnostic framework based on a literature review. Second, we conducted a meta-analysis of findings published in case study papers to identify archetypical configurations of impacts, participatory research approaches, context conditions, and sustainability goals (Rudel 2008, Oberlack and Eisenack 2018). Archetype analysis is increasingly used in sustainability research as a methodological approach to identify recurrent patterns from larger sets of case studies (Oberlack et al. 2019a). Archetypes are generally defined as context-sensitive, generalized models of recurrent patterns of factors and processes that explain the outcome of interest with case-level empirical validity (Eisenack et al. 2006, Sietz 2017). The meta-analysis approach can be seen as a systematization of reported findings from case studies in an integrative language, which allows for abstracting from individual case studies (Jensen and Rodgers 2001).

For the purpose of this study, we consider different schools of participatory research, including transdisciplinary research (Hadorn et al. 2008), codesign and coproduction (Mauser et al. 2013), collaborative and participatory action research (Selener 1997). To provide focus, we limit this study to participatory research approaches aimed at more sustainable agricultural production. These include settings with complex relations between different actors along food, feed, and energy value chains, a high degree of uncertainty because of weather and market dependency, and contradicting objectives and preferences of individual actors (Ericksen 2008, Hamm 2009). Participatory research approaches are generally seen as promising ways to address the diverse problems of different production systems, and have been applied in various settings around the globe (Binder et al. 2012, Monzote et al. 2012, Andersson 2015, Jacobi et al. 2015).

\section{DIAGNOSTIC FRAMEWORK AND METHODOLOGY}

\section{Diagnostic framework}

Answering our research questions required adapting existing frameworks (Walter et al. 2007, Wiek et al. 2014, Mitchell et al. 2015, Luederitz et al. 2017). Although these frameworks focus on the "how" of participatory research processes and their impacts, none of them specifically considers the context conditions in which a project develops, nor the sustainability goal as a motivation for the project. However, these points could play an important role for participatory research approaches and the chosen activities (Schneider and Buser 2018). Ostrom's (2005) institutional analysis and development (IAD) framework provides further inspirations because it allows aligning the above mentioned frameworks with context and sustainability goals (Guimarães et al. 2018).

The developed diagnostic framework links participatory research approaches with contexts, sustainability goals, and impact (Fig. 1). It conceptually defines the engagement of different actors (participatory approach) in specific contexts in order to achieve certain sustainability goals. We presume that the participatory approaches chosen by research projects depended on the sustainability goals and their context. They represent the action situations in which new knowledge is produced, actor interactions take place, and conflicts or synergies arise.

Because the framework is based on different types of studies, it also comprises different types of results of participatory research approaches. These types include what other authors have defined 
as outputs, outcomes, and impacts. However, the exact differences between outputs, outcomes, and impacts do vary across studies. Therefore, for the purpose of this meta-analysis, we placed them all in the impact category, rather than distinguishing between these different types of results. Below we describe the four main components of our diagnostic framework.

Fig. 1. Diagnostic framework: the set of attributes characterizing the components is shown in the codebook in Appendix 2. Solid lines outline elements that were included in this study. Dashed lines outline feedback effects, which are known to take place but were not included in this study.

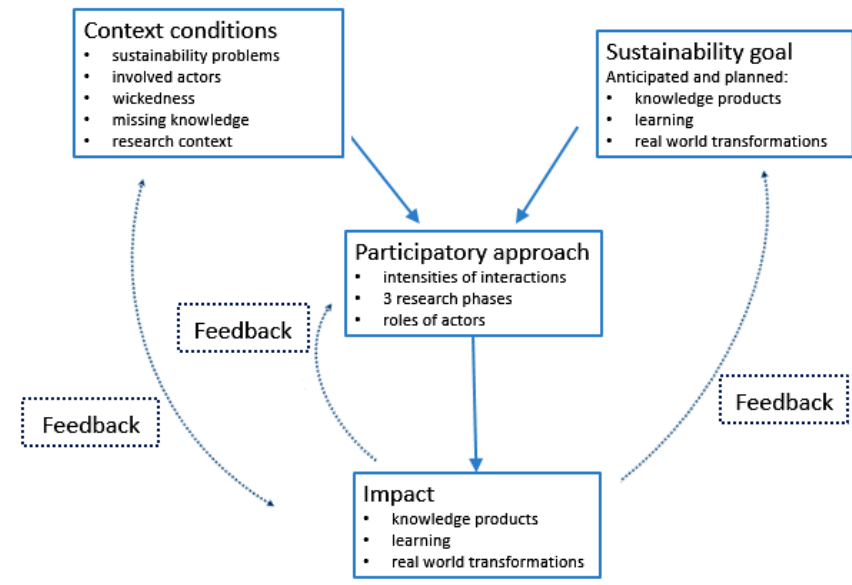

\section{Context conditions}

The context of participatory research projects varies widely along social, economic, political, and ecological conditions (Adler et al. 2018). We included the following context variables: investigated sustainability problems, involved actors, wickedness of the situation, type of missing knowledge, and the research context. The sustainability problem, i.e., resources and environment, socioeconomic, and governance, was chosen because it potentially involves topics, problem constellations, and actor groups that might require different approaches and activities (Schneider and Buser 2018). The degree of wickedness of these problems was part of our framework because participatory research approaches are generally deemed suitable to address higher degrees of wickedness (Brown 2010). The type of missing knowledge - system, target, and transformation knowledge (Proclim/CASS 1997, Pohl and Hirsch Hadorn 2007) - and the actor context (Enengel et al. 2012) were included because they might be decisive for tailoring participatory approaches.

\section{Sustainability goal}

Sustainability goals can vary extensively between participatory research projects, e.g., some focus on the generation of more robust knowledge, others on the empowerment of involved actors and intended behavioral changes. For the purpose of this study, we used the three areas of sustainability goals suggested by Mitchell et al. (2015): knowledge products, learning, and realworld transformations. Although in many cases the ultimate goal of participatory research might be real-world transformations, $i$. e., substantial changes in the social-ecological system, more tangible goals concern knowledge products or learning. Knowledge products refer to decision-making tools, knowledge databases, action plans, and publications. Learning includes the development of ownership, new knowledge, networking, reflection on learning, trust building, self-confidence, capacity building, and communicating best practices. Based on Gibson et al. (2005), we categorized real-world transformations as socialecological integrity, enhanced livelihoods, intra- and intergenerational equity, resource maintenance and efficiency, social-ecological stewardship and democratic governance, and precaution and adaptation.

\section{Participatory approaches}

Interactions between scientific and societal actors can have different intensities. Based on Arnstein (1969), we used the following categories for operationalizing intensity: information (delivering information to societal actors), consultation (inquire into societal actors' opinions, expectations, and preferences), and coproduction of new knowledge (joint knowledge generation between researchers and societal actors during different research phases). Furthermore, we structured the research process along three main phases, namely the joint framing of problems and research questions, the coproduction of new knowledge, and the integration of this newly produced knowledge into science and societal practice (Lang et al. 2012). We also distinguished between different roles scientific and nonscientific actors play in the chosen approaches (Pielke 2014).

\section{Impact}

Impact categories correspond to the categories of sustainability goals, i.e., knowledge products, learning, and real-world transformation. We acknowledge that (a) the process of impact generation is complex and can follow different pathways, e.g., generating specific products or triggering social interactions and learning (Kaufmann-Hayoz et al. 2016). These include feedback effects influencing back on the context, the approach, and the sustainability goal (Fig. 1). Systematic descriptions of these feedback effects were not reported in the case studies and are not considered further; (b) although the investigated case studies used different concepts to categorize impact, we used the term impact in a broader sense without assuming specific sequences of outputs, outcomes, and impacts.

\section{Meta-analysis of case studies using the archetypes approach}

In our study, a case was a participatory research project and a case study was a scientific, peer-reviewed publication that presents the results of whether and how a project generated impact. For analyzing the case studies according to the introduced diagnostic framework, we adopted the study design for archetype analysis by Oberlack et al. (2016) and Oberlack and Eisenack (2018). Archetypes generalize evidence from cases into recurrent patterns, which explain how outcomes arise from particular configurations of conditions and processes (Oberlack et al. 2019a, Sietz et al. 2019). Archetypes are building blocks because a single case can involve multiple archetypes (Eisenack et al. 2019). The present study conducted a meta-analysis of case studies following the three steps of case study retrieval and selection, coding, and data analysis (Magliocca et al. 2015).

Figure 2 presents the detailed study protocol. We first retrieved case studies through a key word search in Scopus and Web of Science, yielding 389 unique references. We selected only those 
Fig. 2. Study protocol.

\begin{tabular}{|c|c|c|}
\hline Step and Objective & How & Result \\
\hline $\begin{array}{l}\text { Key word search in Web of } \\
\text { Science and Scopus }\end{array}$ & $\begin{array}{l}\text { - Key words: (sustainab* AND (agricultur*) AND (transdiscipl* OR "co- } \\
\text { production" OR collab* OR "particip* research" OR co-design OR "action } \\
\text { research") AND (impact OR outcome)) } \\
\text { Publication date: all until June } 2016 \\
\text { - Last search was conducted on } 24 \text { June } 2016 \\
\text { - Merge databases in EndNote X7 and delete the overlaps. }\end{array}$ & $\begin{array}{l}\text { Retrieved documents: } \\
\text { - Web of Science: } 249 \\
\text { - Scopus: } 311 \\
\text { - } 389 \text { unique documents, } \\
\text { after deletion of overlaps }\end{array}$ \\
\hline $\begin{array}{l}\text { Two-step selection: } \\
\text { Exclude retrieved papers that } \\
\text { do not meet inclusion } \\
\text { criteria by screening titles } \\
\text { and abstracts (Step 1) and } \\
\text { full papers (Step 2) }\end{array}$ & $\begin{array}{l}\text { Criteria for inclusion of retrieved papers in the meta-analysis: } \\
\text { Topic and analytical unit: Analysis of sustainability impacts of participatory } \\
\text { research project in the field of transitions to sustainable agriculture. } \\
\text { Methods: Case study design. Study is based on primary data. Study documents } \\
\text { research process in a transparent manner, particularly sources of evidence and } \\
\text { normative, conceptual, and theoretical preconceptions. Studies show all parts of } \\
\text { the diagnostic framework (context, goal, participatory approach and activities, } \\
\text { outcome). } \\
\text { Context: Cases are located in different countries on all continents. }\end{array}$ & $\begin{array}{l}26 \text { documents with } 29 \text { case } \\
\text { studies of participatory } \\
\text { research projects after Step } 2\end{array}$ \\
\hline $\begin{array}{l}\text { Codebook development } \\
\text { and coding }\end{array}$ & $\begin{array}{l}\text { - Identify empirical results of each case study that explain outcomes. } \\
\text { - Develop codebook from literature and through iterative procedure. } \\
\text { Coding of all studies based on the codebook. }\end{array}$ & $\begin{array}{l}\text { - Codebook (Appendix 2) } \\
\text { - } 29 \text { coded cases }\end{array}$ \\
\hline Data analysis & $\begin{array}{l}\text { - Compilation of frequencies for impacts, activities per research phase and impact, } \\
\text { and actor roles } \\
\text { Conduct formal concept analysis (FCA) of configurations of attributes for each of } \\
\text { the impact categories. Quantify frequency of attribute configurations. Adopt } \\
\text { qualitative interpretations and examples from the primary case studies. }\end{array}$ & $\begin{array}{l}\text { - Archetypes of sustainability } \\
\text { impacts of participatory } \\
\text { research approaches }\end{array}$ \\
\hline
\end{tabular}

papers that met all inclusion criteria (Fig. 2); 26 papers were finally included in the meta-analysis (list of included case studies in Appendix 1). They cover 29 cases of participatory research projects located in 7 countries in Europe, 1 in North America, 10 in Africa, 3 in Asia Pacific, 1 in Central Asia, and 2 in Latin America. Some studies highlight their approaches and methodologies, some report about their findings and results in detail, and others reflect on the scientific and societal impacts of their projects.

We coded the case studies using MaxQDA software and the codebook, which is based on our diagnostic framework (Appendix 2). Correspondingly, we coded the reported impacts, participatory approaches, goals, and context conditions for each case study. The first author coded all 26 case studies; the second and third authors independently coded 5 papers each. The coding team kept consistent codings and resolved disagreements by discussing them and agreeing on the final code. The resulting dataset consisted of 29 cases characterized by the reported attributes per case. Using the 154 attributes of the codebook, we found 653 codes in total with some of the attributes reported frequently and others few or zero times.

Data analysis followed two steps. First, we compiled frequencies of what the studies reported on impacts, activities per research phase, and actor roles. This provides a descriptive overview of processes and impacts. Second, we applied formal concept analysis (FCA) to identify archetypical patterns in the data set (Ganter and Wille 1999) using the Concept Explorer software. FCA is a set-theoretic methodology that analyzes the dataset by compiling logical implications between attributes. It generates a concept lattice, which organizes attributes in a hierarchical structure so that higher level attributes are logical implications of connected lower level attributes, whereas lower level attributes show distinct combinations with higher level attributes (Oberlack et al. 2016, Oberlack and Eisenack 2018). We compiled the concept lattices for each of the impact categories reported to have been achieved, i.e., learning, knowledge products, and real-world transformations. For each impact category, we analyzed what participatory approaches, goals, and context conditions are recurrently associated with a particular impact, and we recorded the frequency for each association. In line with the design standards of Eisenack et al. (2019), we used a frequency threshold. We only report associations that were reported in at least $20 \%$ of all cases with a particular kind of impact in order to identify only associations that are recurrent.

\section{Limitations}

The first limitation relates to potential publication biases and missing data. Both points are well-known to meta-analytical 
methodologies (van Vliet et al. 2016). Authors of primary studies have their own reasoning for why they report certain findings and not others. The often brief descriptions of research processes in primary studies limit our analysis because we could not find information for all our framework variables even if they were deemed important. Such examples included research conditions, the degree of wickedness, or power relations (Pohl and Hirsch Hadorn 2008, Reed 2008, Brown 2010, Avelino and Wittmayer 2016). Unreported findings can mean they were unimportant to the primary study or they were not covered; both points cannot be verified here. In addition, research "failures" are often difficult to publish despite their important learning potential for others. Furthermore, any meta-analysis faces the challenge that primary studies may have omitted variables, i.e., attributed impacts to false causes. To reduce this problem, we used methodological inclusion criteria (Fig. 2) to ensure credibility of primary case studies. Furthermore, the codebook in Appendix 2 may be a starting point to address problems of omitted variables and missing data in future studies.

Second, it is difficult to assess cause and effect because of the lack of sufficient details in many of the primary studies. It is likely that other, unmentioned events contributed to the reported impact. Based on our methodological inclusion criteria, we assumed that reported impacts were related to the applied methods and approaches to a certain degree as reported in the primary studies, which were all published in peer-reviewed, scientific journals. However, we cannot verify that reported impacts actually happened. Hence, the synthesized effects of our study need to be rigorously tested in future empirical studies.

The results of this paper should be understood as a systematization of the available framings and scientific evidence on how participatory research approaches contribute to impact. They synthesize previously scattered evidence of 29 cases into archetypical patterns, which provide insights into generalizable patterns, highlight diversity across cases, and may inspire new empirical research. They show that archetypical configurations exist in the field of agriculture and can be usefully depicted but we do not claim representativeness of the retrieved configurations for the global universe of cases.

\section{RESULTS}

The results show that the participatory research projects in our sample generated three main types of impacts: learning, knowledge products, and real world-transformations. Each of these impacts arose from particular intensities of interactions, contexts, and sustainability goals. To gain insight into the commonalities and diversity of the cases, we also provide descriptive statistics showing disaggregated data for activities, impacts, actor roles, and intensity of actor interactions.

\section{Archetype learning}

Of the 29 cases, 22 reported learning as a main impact (Fig. 3) and 17 highlighted learning among others as the intended sustainability goal. Learning was reported in diverse ways, including providing new knowledge, capacity building, trust, selfconfidence, or ownership (Fig. 4). Examples included new knowledge for societal actors about methods for pest and disease management (Oettlé et al. 2004), reducing soil erosion (Bagshaw and Lindsay 2009), strategy development and action-oriented knowledge for regional development (Breu et al. 2005), or technical knowledge about seedling production (Akpo et al. 2015). In some cases this knowledge was jointly produced while in others it was disseminated to actors. Other examples were insights from joint reflections of participants on what they had learned, increased trust because of the process, and improved capacity to deal with daily challenges. Several cases used activities that are not so common such as interactive site visits, field experiments, and participatory filmmaking to support educational and learning experiences. Such activities serve to better embed and empower farmers in the knowledge production process. They are also practical means for participants to engage in new topics.

Fig. 3. Archetypical configuration for the reported impact learning (attributes and connections above the threshold are in color, below the threshold or unreported are light grey). Numbers indicate the frequencies of each attribute. Ph1 to $3=$ research phases 1 to 3 ; inf $=$ information; cons = consultation; coprod $=$ coproduction.

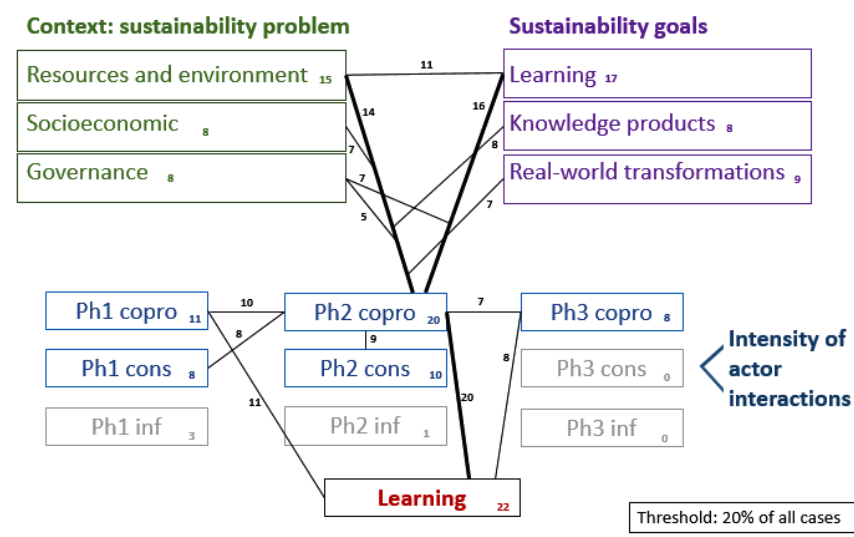

Fig. 4. Detailed impact information for each of the archetypes. Multiple bars per impact indicate coreporting of impact.

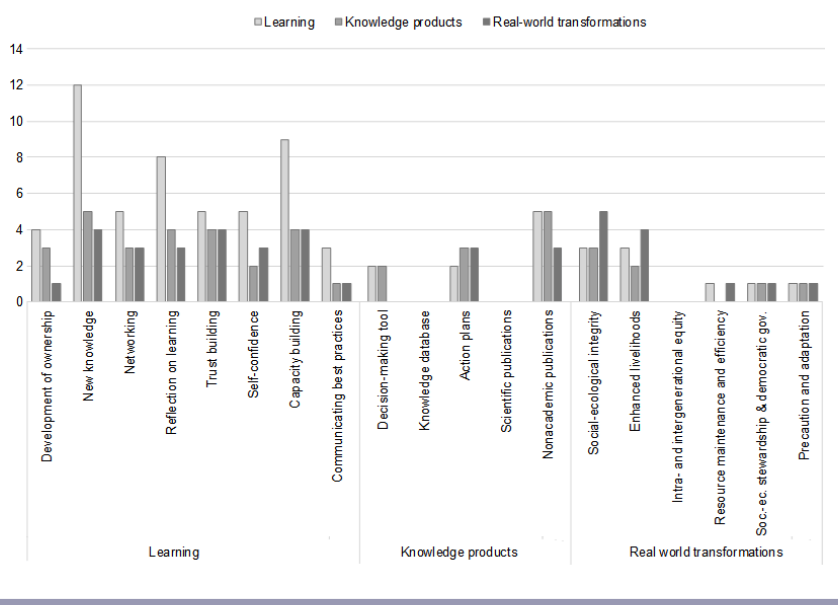


Table 1. Frequencies of reported sustainability problems in the impact learning.

\begin{tabular}{|c|c|c|c|c|c|c|}
\hline \multicolumn{2}{|c|}{ Sustainability problem } & \multirow{2}{*}{$\begin{array}{c}\text { Count } \\
1 \\
16\end{array}$} & $\begin{array}{c}\begin{array}{c}\text { Sum of } \\
\text { subgroups }\end{array} \\
22\end{array}$ & $\begin{array}{c}\% \\
38.5\end{array}$ & $\begin{array}{c}\begin{array}{c}\text { Sum of learning } \\
\text { cases }\end{array} \\
15\end{array}$ & $\begin{array}{l}\% \\
48\end{array}$ \\
\hline $\begin{array}{l}\text { Resources and } \\
\text { environment }\end{array}$ & $\begin{array}{l}\text { Competition } \\
\text { Degradation } \\
\text { Pollution }\end{array}$ & & 22 & 38.5 & 15 & 48 \\
\hline Socioeconomic & $\begin{array}{l}\text { Economic viability } \\
\text { Markets } \\
\text { Population pressure } \\
\text { Poverty } \\
\text { Gender } \\
\text { Dependency }\end{array}$ & $\begin{array}{l}5 \\
5 \\
0 \\
3 \\
3 \\
2\end{array}$ & 18 & 31.5 & 8 & 26 \\
\hline Governance & $\begin{array}{l}\text { Access } \\
\text { Distribution } \\
\text { Mismanagement } \\
\text { Total }\end{array}$ & $\begin{array}{c}6 \\
3 \\
8 \\
57\end{array}$ & 17 & 100 & 31 & 26 \\
\hline
\end{tabular}

A majority of cases that reported learning took place in the context of problems related to resources and environment, which concerned soil problems, water problems, or land degradation and desertification. Appendix 3 gives an overview of all reported sustainability problems in the included case studies. These occurred usually in combination with socioeconomic problems such as poverty, declining margins, and high costs, and repeatedly in combination with governance problems such as insufficient governmental services and infrastructure or mismanagement of natural resources. Many of the cases address complex, crosssectoral problems. Table 1 shows the frequencies of each reported sustainability problem for the main variables and the second order variables. Although projects address environmental, socioeconomic, and governance problems with similar frequencies $(38 \%, 31 \%$, and $30 \%$ of all cases, respectively), learning is reported considerably more often as an impact if projects address problems of resources and the environment.

The pattern shows the significance of coproduction as opposed to consultation or information activities (Fig. 3). Coproduction is particularly important in the second research phase of reported learning cases ( 20 of 22 cases). Coproduction in the second phase involved, for example, regular meetings to discuss new insights on nutrient issues (Cabrera et al. 2008), a system analysis workshop to assess the sustainability in the milk value chain (Binder et al. 2012), or participatory scenario-building workshops for a more sustainable irrigated agriculture (Soste et al. 2015). Half of these cases are associated with coproduction in phase 1 and slightly fewer with coproduction in phase 3 . Consultation is used frequently in phases 1 and 2 but always together with coproduction.

The main activities in phase 1 associated with learning are the joint definition of objectives and questions, joint problem identification and definition, and agreed-upon methodology for coproduction (Fig. 5). In phase 2, the integration of different types of knowledge from experts, farmers, and scientists were important as well as the application of integrative methods such as participatory filmmaking. For phase 3 , the studies reported the integration of knowledge into societal practice and the evaluation of impact.
Fig. 5. Detailed information for activities in each of the reported impacts in research phases 1-3.

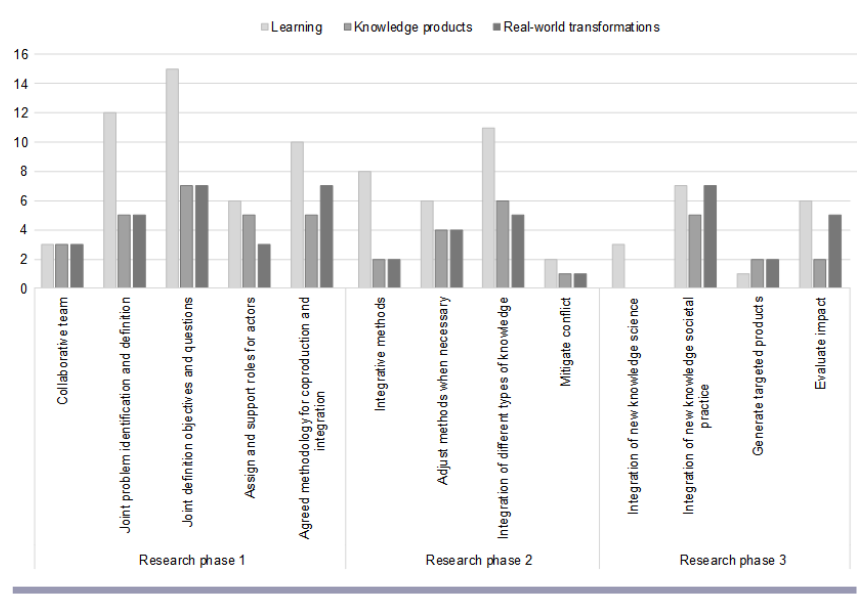

\section{Archetype knowledge products}

Ten cases reported impact in the form of knowledge products (Fig. 6). These knowledge products (Fig. 4) ranged from whole farm decision-support systems in Florida (Cabrera et al. 2008) and a sustainability assessment tool for the milk value chain in Switzerland (Binder et al. 2012), over action plans for less polluting banana production in Australia (Bagshaw and Lindsay 2009) to training material for palm seed nurseries in Benin (Akpo et al. 2015).

The archetypical configuration for knowledge products was less clear than for learning. We found a strong interlinked presence of reported coproduction in all three phases. The investigated case studies may have embedded the creation of new knowledge products well throughout the entire research process in order to increase chances for a successful implementation. The goal learning coupled with coproduction in phases 1 and 2 supported this hypothesis by emphasizing the need for a comprehensive understanding of how to design and implement such knowledge products. An example of this is a decision-support system to decrease nitrogen leaching in dairy farming (Cabrera et al. 2008). 
The project's approach involved participatory workshops in phase 1 to coproduce certain model parameters, in phase 2 to jointly reflect on new scientific evidence on nutrient issues, and in phase 3 to evaluate the product and test its applicability.

Fig. 6. Archetypical configuration for the reported impact knowledge products (attributes and connections above the threshold are in color, below the threshold or unreported are light grey). Numbers indicate the frequencies of each attribute. $\mathrm{Ph} 1$ to $3=$ research phases 1 to 3 ; inf = information; cons = consultation; coprod $=$ coproduction .

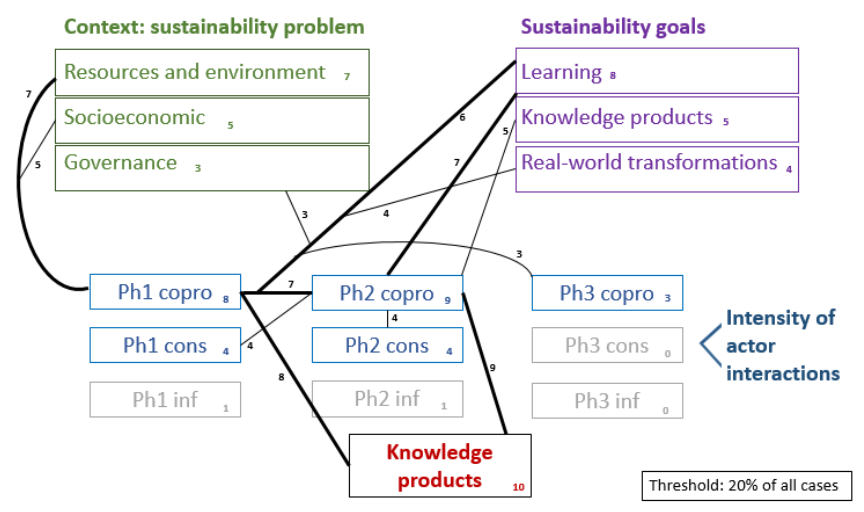

Reported coproduction activities in phases 1 and 2 included jointly defining objectives and questions, joint identification and definition of problems, agreed-upon methodology for coproduction, and assign and support roles for actors (Fig. 5). Reported activities in phase 2 were the integration of different types of knowledge and the adjustment of methods when necessary, while phase 3 was mainly related to the integration of knowledge into societal practice.

\section{Archetype real-world transformations}

Ten cases reported real world transformation impacts (Fig. 7), mainly social-ecological integrity and enhanced livelihoods. Examples included the establishment of a whole new value chain of wild rooibos production and marketing within a cooperative (Oettlé et al. 2004); or increased food security and health, better environmental performance, higher incomes, and improved communal life as a consequence of more sustainable agricultural practices (Wright 2014). Examples for enhanced livelihoods include reported improvements of daily lives of people through better production methods (Andersson 2015) and new policies tailored to customers' needs for taxing irrigation water (Dedrick et al. 2000). Impacts on resource maintenance and efficiency, social-ecological stewardship and democratic governance, and precaution and adaptation were only reported once, while intraand intergenerational equity was not reported (Fig. 4).

Projects aiming to achieve real-world transformations not only reported complex, interrelated contexts but also featured a combination of different sustainability goals while coproduction is pronounced in all three research phases. Reported activities mainly included agreed-upon methodology for coproduction and jointly defined objectives and questions in phase 1 (Fig. 5). These included joint proposals defining who should participate when and how in knowledge production or participatory workshops for creating visions where everyone's objectives were considered (Oettlé et al. 2004). Phase 2 mainly contained the subcategory adjusting methods when necessary. An example here is a flexible, farmer-led but research-based approach for developing solutions for sustainable local agriculture (Mog 2006). Examples for the integration of knowledge into societal practice in phase 3 are knowledge transfers through collaborations with extension services for farmers' concerns and a wide range of education activities to inform societal actors about research results (Mog 2006).

Fig. 7. Archetypical configuration for the reported impact realworld transformations (attributes and connections above the threshold are in color, below the threshold or unreported are light grey). Numbers indicate the frequencies of each attribute. $\mathrm{Ph} 1$ to $3=$ research phases 1 to 3 ; inf $=$ information; cons $=$ consultation; coprod $=$ coproduction .

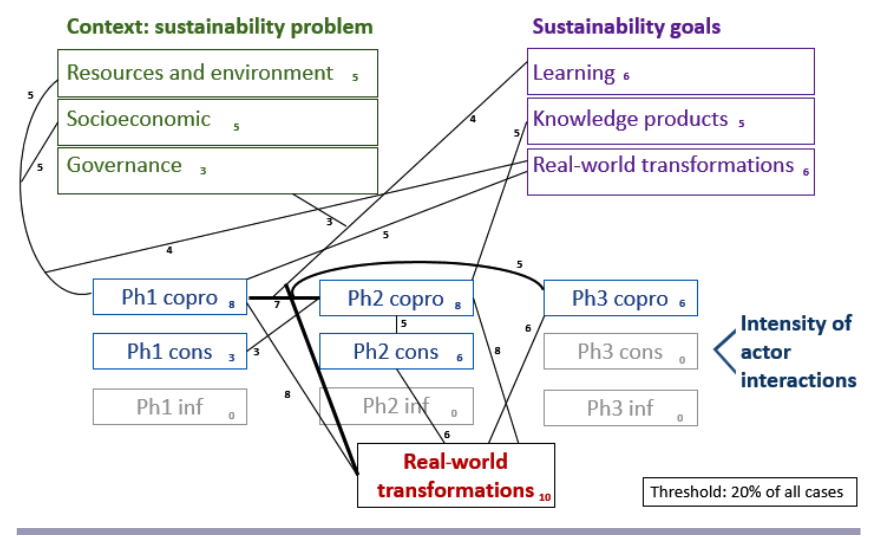

Descriptive statistics on actor roles, intensity, and achievement of sustainability goals

Figure 8 highlights the reported roles of scientific and societal actors, which vary substantially for the different impact categories. For learning, the case studies reported that societal actors were predominantly knowledge producers, followed by facilitators and experts, while scientific actors were most often facilitators and knowledge producers. The archetypes for knowledge products and real-world transformations showed similar patterns.

Fig. 8. Reported roles of scientific and societal actors in activities with reported impacts.

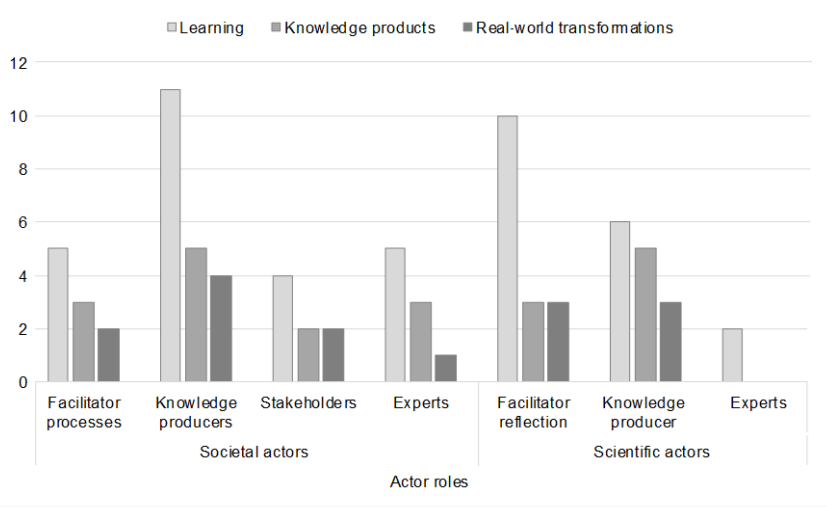


Reported intensity of actor interactions covered the entire spectrum from information to coproduction, but high intensities of actor interactions were most prevalent. Table 2 shows reported coproduction cases in all research phases. For example, in the learning archetype, 11 coproduction cases were reported in phase 1 , which corresponds to $50 \%$ of all learning cases. In over $80 \%$ of all cases, coproduction was reported in phase 2 , over $50 \%$ in phase 1 , and over $30 \%$ in phase 3 (Table 2). The numbers were also high across phases 1 and $2(45-70 \%)$ and across all three phases (23$50 \%$ ).

Table 2. Reported coproduction cases in research phases 1-3 for the three archetypes.

\begin{tabular}{|c|c|c|c|c|c|c|}
\hline $\begin{array}{l}\text { Research } \\
\text { phase }\end{array}$ & $\begin{array}{l}\text { Archetype } \\
\text { Learning } \\
\text { (n) }\end{array}$ & $\%$ & $\begin{array}{l}\text { Archetype } \\
\text { Knowledge } \\
\text { products } \\
\text { (n) }\end{array}$ & $\%$ & $\begin{array}{l}\text { Archetype } \\
\text { Real-world } \\
\text { transformat- } \\
\text { ions (n) }\end{array}$ & $\%$ \\
\hline 1 & 11 & 50 & 8 & 80 & 8 & 80 \\
\hline 2 & 20 & 91 & 9 & 90 & 8 & 80 \\
\hline 3 & 8 & 36 & 3 & 30 & 6 & 60 \\
\hline $1 \& 2$ & 10 & 45 & 7 & 70 & 7 & 70 \\
\hline $2 \& 3$ & 7 & 32 & 0 & 0 & 0 & 0 \\
\hline $1 \& 2 \& 3$ & 5 & 23 & 3 & 30 & 5 & 50 \\
\hline $\begin{array}{l}\text { Total } \\
\text { number of } \\
\text { cases }\end{array}$ & 22 & 100 & 10 & 100 & 10 & 100 \\
\hline
\end{tabular}

Furthermore, we compared the reported impacts to their sustainability goals. Table 3 shows the number of cases for each reported sustainability goal and impact. Some of the variations probably stemmed from misperceptions of planned impacts, e.g., scientific publication planned but societal publication achieved. Others were difficult to assess in terms of percentages because of very small case numbers, e.g., decision-making tools or the real world transformation impacts.

\section{DISCUSSION}

Our results show that different reported impacts involve different intensities of actor interactions throughout the three research phases. Case studies with the learning archetype reported the majority of coproduction activities in phase 2, while impacts in knowledge products and real-world transformations were reported with coproduction in all three research phases, which might be because of the complexity of such problems demanding a broad range of involved actors throughout the research process. This is in line with the findings of Schneider and Buser (2018). The most pronounced use of coproduction throughout the whole research process can be observed in real world transformation impacts. This seems to be only partly in line with previous findings by Herrero et al. (2019) who highlight the importance of coconstructing research questions and problem framings to achieve social learning. However, it has to be noted that the analyses are not directly comparable because Herrero et al. do not work with the three research phases by Lang et al. (2012) and focus more, in our terminology, on the first phase of participatory research projects. Newig et al. (2019) also find a positive effect of early involvement of societal actors in the formulation of problems and the definition of research questions for societal impact but they do not find a general positive impact of societal actor involvement over the whole length of the research process.
Zscheischler et al. (2018) find that the perception of success in transdisciplinary research is strongly linked to practical solutions for societal problems. In this regard, intense actor interactions in knowledge products and real-world transformations seems reasonable because we can assume that they depend more on practical solutions.

Furthermore, we observe that the archetypes knowledge products and real-world transformations feature more interlinkages between sustainability problems and sustainability goals and have more intense actor interactions than the learning archetype. We assume that the former two archetypes involve more complexity and contestation because the actual finding of solutions for complex societal problems is more challenging than learning, especially in view of our definition of learning, which apart from social learning (Herrero et al. 2019) also includes individual learning. Following this line of argument, impacts of knowledge products and real world transformation should be better addressed through more intense actor interactions (Schneider and Buser 2018). Our results show that case studies with the learning archetype more often report that their sustainability goals were achieved. Although learning may be achieved more easily, higher complexity and contestation in knowledge products and realworld transformations may make it more difficult to reach sustainability goals.

The included case studies describe the roles of societal actors as knowledge producers rather than mere knowledge receivers, whereas scientific actors frequently take up the role of facilitators because of the need to integrate societal actors in the knowledge production process and to address issues of credibility and legitimacy during the process (Pohl et al. 2010). These new roles also demand a different type of training for researchers engaging in such projects in order to address power imbalances and create trust among the participants, which are seen as key factors for impact in social learning (Herrero et al. 2019) and decision making (Newig et al. 2018).

Our findings show that the initial sustainability goals at the start of a project can diverge from the reported impacts (Table 3). Although some of the case studies reported achievements of their stated goals, others did not or ended with unenvisioned impacts. Other authors have discussed these in terms of impact or success of participatory research, which is generally difficult to trace (Walter et al. 2007, Polk 2015, Klenk and Meehan 2017, Luederitz et al. 2017, Zscheischler et al. 2018). Relating project impacts to previously defined goals highlights the necessity to reflect on and engage with mechanisms that evolve during a project, for instance through a theory of change approach (Oberlack et al. 2019b).

The archetype approach provided the methodological basis for this study (Eisenack et al. 2006, Sietz et al. 2019). The understanding of archetypes as building blocks (Eisenack et al. 2019, Oberlack et al. 2019a) allowed us to synthesize the explanations of diverse impacts reported in the case studies into a typology, which we find parsimonious and detailed at the same time. Earlier archetype studies found that their cases differed strongly with regard to the processes and causal mechanisms that generate the impacts of concern (e.g., Sietz et al. 2011, Oberlack et al. 2016, Sietz 2017, Levers et al. 2018) or with regard to socialecological conditions (e.g., Václavík et al. 2016). In our paper, we found the largest variety in the reported impacts, whereas reported 
Table 3. Comparison of reported sustainability goals and impacts.

\begin{tabular}{|c|c|c|c|c|c|c|}
\hline$\underline{\text { Sustainability goal }}$ & Variable & $\mathrm{N}$ & Impact & Variable & $\mathrm{N}$ & Corresponding cases \\
\hline Knowledge products & Action plans & 6 & Knowledge products & Action plans & 3 & 1 \\
\hline Knowledge products & Decision-making tool & 2 & Knowledge products & Decision-making tool & 2 & 1 \\
\hline Knowledge products & Scientific publications & 2 & Knowledge products & Scientific publications & 0 & 0 \\
\hline Knowledge products & Nonacademic publications & 1 & Knowledge products & $\begin{array}{l}\text { Nonacademic } \\
\text { publications }\end{array}$ & 5 & 0 \\
\hline Learning & New knowledge & 13 & Learning & New knowledge & 12 & 6 \\
\hline Learning & Capacity building & 6 & Learning & Capacity building & 9 & 4 \\
\hline Learning & Best practices & 4 & Learning & Best practices & 3 & 1 \\
\hline Learning & Reflection & 2 & Learning & Reflection & 8 & 1 \\
\hline Learning & Development of ownership & 2 & Learning & $\begin{array}{l}\text { Development of } \\
\text { ownership }\end{array}$ & 4 & 1 \\
\hline Learning & Self confidence & 0 & Learning & Self confidence & 5 & 0 \\
\hline Learning & Networking & 1 & Learning & Networking & 5 & 0 \\
\hline Learning & Trust building & 0 & Learning & Trust building & 5 & 0 \\
\hline $\begin{array}{l}\text { Real world } \\
\text { transformations }\end{array}$ & Social-ecological integrity & 5 & $\begin{array}{l}\text { Real-world } \\
\text { transformations }\end{array}$ & Social-ecological integrity & 5 & 1 \\
\hline $\begin{array}{l}\text { Real world } \\
\text { transformations }\end{array}$ & Livelihoods & 4 & $\begin{array}{l}\text { Real-world } \\
\text { transformations }\end{array}$ & Livelihoods & 4 & 2 \\
\hline $\begin{array}{l}\text { Real world } \\
\text { transformations }\end{array}$ & $\begin{array}{l}\text { Resource maintenance and } \\
\text { efficiency }\end{array}$ & 3 & $\begin{array}{l}\text { Real-world } \\
\text { transformations }\end{array}$ & $\begin{array}{l}\text { Resource maintenance } \\
\text { and efficiency }\end{array}$ & 1 & 0 \\
\hline $\begin{array}{l}\text { Real world } \\
\text { transformations }\end{array}$ & $\begin{array}{l}\text { Intra- and intergenerational } \\
\text { equity }\end{array}$ & 0 & $\begin{array}{l}\text { Real-world } \\
\text { transformations }\end{array}$ & $\begin{array}{l}\text { Intra- and } \\
\text { intergenerational equity }\end{array}$ & 0 & 0 \\
\hline $\begin{array}{l}\text { Real world } \\
\text { transformations }\end{array}$ & $\begin{array}{l}\text { Social-ecological } \\
\text { stewardship and democratic } \\
\text { gov. }\end{array}$ & 1 & $\begin{array}{l}\text { Real-world } \\
\text { transformations }\end{array}$ & $\begin{array}{l}\text { Social-ecological } \\
\text { stewardship and } \\
\text { democratic gov. }\end{array}$ & 1 & 0 \\
\hline $\begin{array}{l}\text { Real world } \\
\text { transformations }\end{array}$ & Precaution and adaptation & 1 & $\begin{array}{l}\text { Real-world } \\
\text { transformations }\end{array}$ & $\begin{array}{l}\text { Precaution and } \\
\text { adaptation }\end{array}$ & 1 & 0 \\
\hline
\end{tabular}

processes were dominated by coproduction activities. This shows that, within a given dataset, analysts can search for archetypes using different entry points including the search for archetypical impacts, processes, or conditions.

\section{CONCLUSION}

The question about sustainability impacts in participatory research approaches is one of the research frontiers in this field, as evidenced by numerous conferences and conference sessions in 2019, the compilation of a Special Issue (Schäfer et al. 2020), a number of ongoing research projects on this theme, as well as ongoing debates in Future Earth. This paper contributes to this topical debate by introducing a diagnostic framework, which relates participatory research approaches to their project contexts, sustainability goals, and reported impacts. We used this framework to synthesize evidence from 29 systematically selected, coded, and analyzed case studies in the field of sustainable agriculture to identify archetypical configurations of impacts in participatory research. We did not engage in primary data collection on impacts but we coded the impacts as they were reported in the selected, peer-reviewed primary studies. Thus, our results should be understood as a synthesis of knowledge in the field instead of a comparative analysis of primary data. Hence, this paper goes beyond the analyses of one or few case studies in most publications on this theme and compares different participatory research approaches in an archetype analysis.

We show that there are distinct archetypes with different participatory research approaches that are associated with impact and in which coproduction rather than mere information or consultation plays an important role. Coproduction activities were more prevalent than information or consultation activities in cases of complex sustainability problems. Although information was not a recurrent pattern, consultation processes occurred often but mostly in combination with coproduction. Complex situations with a higher diversity of sustainability problems and goals are associated with more intense actor interactions throughout the entire research process. Although learning is mainly linked to coproduction in phases 1 and 2, the archetypes knowledge products and real-world transformations involve coproduction in all three research phases. It has to be considered that the typical time frame of research projects spans around three years. This is rather short for achieving real-world transformation impacts, even more so when they concern intraand intergenerational justice (not reported in any of the case studies). Longer time frames are needed for evaluation activities. Impacts in learning or knowledge products seem to be more feasible within shorter project time frames.

Finally, with this paper we contribute to methodologies of archetypes analysis. It provides important methodological lessons on the potentials and pitfalls of FCA for archetype analysis. FCA has enabled us to disentangle the archetypical configurations of impacts, participatory research approaches, contexts, and sustainability goals, as reported by the 29 case studies. A challenge in our analysis was insufficient information for some of our framework variables. Limited reporting in primary studies often constrains the scope of meta-analyses (van Vliet et al. 2016). Hence, a coherent way of reporting on participatory research, including methodology, lessons learned, and failures of different approaches is strongly needed. 
We believe that the diagnostic framework and the archetypical patterns found in this paper contribute to more coherent understanding of how participatory research projects from different traditions can and do trigger sustainability impacts. The diagnostic framework and the associated attributes provided in the codebook (Appendix 2) can be considered in future research for deciding what factors might be important in a participatory research project.

Responses to this article can be read online at: http://www.ecologyandsociety.org/issues/responses. php/11517

\section{Acknowledgments: \\ We thank the anonymous reviewers for their helpful comments.}

\section{Data Availability Statement:}

Datalcode openly available in a public repository that issues datasets with DOIs.

\section{LITERATURE CITED}

Adler, C., G. Hirsch Hadorn, T. Breu, U. Wiesmann, and C. Pohl. 2018. Conceptualizing the transfer of knowledge across cases in transdisciplinary research. Sustainability Science 13:179-190. https://doi.org/10.1007/s11625-017-0444-2

Akpo, E., T. A. Crane, P. V. Vissoh, and R. C. Tossou. 2015. Coproduction of knowledge in multi-stakeholder processes: analyzing joint experimentation as social learning. Journal of Agricultural Education \& Extension 21:369-388. https://doi. org/10.1080/1389224X.2014.939201

Andersson, E. 2015. Turning waste into value: using human urine to enrich soils for sustainable food production in Uganda. Journal of Cleaner Production 96:290-298. https://doi.org/10.1016/j. jclepro.2014.01.070

Arnstein, S. R. 1969. A ladder of citizen participation. Journal of the American Planning Association 35:216-224.

Avelino, F., and J. M. Wittmayer. 2016. Shifting power relations in sustainability transitions: a multi-actor perspective. Journal of Environmental Policy \& Planning 18:628-649. https://doi. org/10.1080/1523908X.2015.1112259

Bagshaw, J., and S. Lindsay. 2009. Developing sustainable banana production systems: a case study from tropical Australia. Acta Horticulturae 831:23-30. https://doi.org/10.17660/ActaHortic.2009.831.2

Bergmann, M., M. Schäfer, and T. Jahn. 2017. Wirkungen verstehen und feststellen. Arbeitspapier aus dem BMBFVerbundprojekt TransImpact, Frankfurt am Main/Berlin, Germany.

Binder, C. R., A. Schmid, and J. K. Steinberger. 2012. Sustainability solution space of the Swiss milk value added chain. Ecological Economics 83:210-220. https://doi.org/10.1016/j. ecolecon.2012.06.022
Blackstock, K. L., G. J. Kelly, and B. L. Horsey. 2007. Developing and applying a framework to evaluate participatory research for sustainability. Ecological Economics 60:726-742. https://doi. org/10.1016/j.ecolecon.2006.05.014

Bornmann, L. 2013. What is societal impact of research and how can it be assessed? A literature survey. Journal of the American Society for Information Science and Technology 64:217-233. https://doi.org/10.1002/asi.22803

Brandt, P., A. Ernst, F. Gralla, C. Luederitz, D. J. Lang, J. Newig, F. Reinert, D. J. Abson, and H. von Wehrden. 2013. A review of transdisciplinary research in sustainability science. Ecological Economics 92:1-15. https://doi.org/10.1016/j.ecolecon.2013.04.008

Breu, T., D. Maselli, and H. Hurni. 2005. Knowledge for sustainable development in the Tajik Pamir Mountains. Mountain Research and Development 25:139-146. https://doi.org/10.1659/0276-4741 (2005)025[0139:KFSDIT]2.0.CO;2

Brown, V. A. 2010. Tackling wicked problems through the transdisciplinary imagination. Earthscan, London, UK.

Buxton, M., and S. Hanney. 1996. How can payback from health research be assessed? Journal of Health Services Research and Policy 1:35-43. https://doi.org/10.1177/135581969600100107

Cabrera, V. E., N. E. Breuer, and P. E. Hildebrand. 2008. Participatory modeling in dairy farm systems: a method for building consensual environmental sustainability using seasonal climate forecasts. Climatic Change 89:395-409. https://doi. org/10.1007/s10584-007-9371-z

Cash, D., W. C. Clark, F. Alcock, N. M. Dickson, N. Eckley, and J. Jäger. 2002. Salience, credibility, legitimacy and boundaries: linking research, assessment and decision making. KSG Working Papers Series RWP02-046. Kennedy School of Government, Harvard, Cambridge, Massachusetts, USA. https://doi. org/10.2139/ssrn.372280

de Jong, S. P. L., T. Wardenaar, and E. Horlings. 2016. Exploring the promises of transdisciplinary research: a quantitative study of two climate research programmes. Research Policy 45 (7):1397-1409. https://doi.org/10.1016/j.respol.2016.04.008

Dedrick, A. R., E. Bautista, W. Clyma, D. B. Levine, and S. A. Rish. 2000. The management improvement program (MIP): a process for improving the performance of irrigated agriculture. Irrigation and Drainage Systems 14:5-39. https://doi.org/10.1023/ A:1006325314944

Economic and Social Research Council (ESRC). 2011. Branching out. New directions in impact evaluation from the ESRC's evaluation committee. ESRC, Swindon, UK. [online] URL: https://esrc.ukri.org/files/research/research-and-impact-evaluation/ branching-out-new-directions-in-impact-evaluation-from-the-esrcs-evaluation-committee/

Eisenack, K., M. Lüdeke, and J. Kropp. 2006. Construction of archetypes as a formal method to analyze social-ecological systems. In IDGEC Synthesis Conference of the Institutional Dimensions of Global Environmental Change. Bali, Indonesia, 6-9 December. International Human Dimensions Programme of Global Environmental Change, Bonn, Germany. [online] URL: https://uol.de/fileadmin/user_upload/wire/fachgebiete/envdev/download/ arch-eisenack3.pdf 
Eisenack, K., S. , S. Villamayor-Tomas, G. Epstein, C. Kimmich, N. Magliocca, D. Manuel-Navarrete, C. Oberlack, M. Roggero, and D. Sietz. 2019. Design and quality criteria for archetype analysis. Ecology and Society 24(3):26. https://doi.org/10.5751/ ES-10855-240306

Enengel, B., A. Muhar, M. Penker, B. Freyer, S. Drlik, and F. Ritter. 2012. Co-production of knowledge in transdisciplinary doctoral theses on landscape development-an analysis of actor roles and knowledge types in different research phases. Landscape and Urban Planning 105:106-117. https://doi.org/10.1016/j. landurbplan.2011.12.004

Ericksen, P. J. 2008. Conceptualizing food systems for global environmental change research. Global Environmental Change 18:234-245. https://doi.org/10.1016/j.gloenvcha.2007.09.002

Folke, C., T. Hahn, P. Olsson, and J. Norberg. 2005. Adaptive governance of social-ecological systems. Annual Review of Environment and Resources 30:441-473. https://doi.org/10.1146/ annurev.energy.30.050504.144511

Ganter, B., and R. Wille. 1999. Formal concept analysis: mathematical concept analysis. Springer, Berlin, Germany.

Gibson, R. B., S. Hassan, S. Holtz, J. Tansey, and G. Whitelaw. 2005. Sustainability assessment: criteria and processes. Earthscan, London, UK. https://doi.org/10.4324/9781849772716

Godin, B., and J. Dore. 2005. Measuring the impacts of science: beyond the economic dimension. Helsinki Institute for Science and Technology Studies, HIST Lecture, Helsinki, Finland.

Guimarães, M. H., N. Guiomar, D. Surová, S. Godinho, T. Pinto Correia, A. Sandberg, F. Ravera, and M. Varanda. 2018. Structuring wicked problems in transdisciplinary research using the social-ecological systems framework: an application to the montado system, Alentejo, Portugal. Journal of Cleaner Production 191:417-428. https://doi.org/10.1016/j.jclepro.2018.04.200

Hadorn, G. H., S. Biber-Klemm, W. Grossenbacher-Mansuy, H. Hoffmann-Riem, D. Joye, C. Pohl, U. Wiesmann, and E. Zemp. 2008. The emergence of transdisciplinarity as a form of research. Pages 19-39 in G. Hirsch Hadorn, H. Hoffmann-Riem, S. BiberKlemm, W. Grossenbacher-Mansuy, D. Joye, C. Pohl, U. Wiesmann, and E. Zemp, editors. Handbook of transdisciplinary research. Springer, Dordrecht, The Netherlands. https://doi. org/10.1007/978-1-4020-6699-3

Hamm, M. W. 2009. Principles for framing a healthy food system. Journal of Hunger \& Environmental Nutrition 4(3-4):241-250. https://doi.org/10.1080/19320240903321219

Herrero, P., T. Dedeurwaerdere, and A. Osinski. 2019. Design features for social learning in transformative transdisciplinary research. Sustainability Science 14:751-769. https://doi. org/10.1007/s11625-018-0641-7

Huutoniemi, K. 2014. Introduction: sustainability, transdisciplinarity and the complexity of knowing. Chapter 1 in $\mathrm{K}$. Huutoniemi and P. Tapio, editors. Transdisciplinary sustainability studies: a heuristic approach. Routledge, London, UK. https://doi. org/10.4324/9780203734834

Jacobi, J., M. Schneider, P. Bottazzi, M. Pillco, P. Calizaya, and S. Rist. 2015. Agroecosystem resilience and farmers' perceptions of climate change impacts on cocoa farms in Alto Beni, Bolivia. Renewable Agriculture and Food Systems 30(2):170-183. https:// doi.org/10.1017/S174217051300029X

Jensen, J. L., and R. Rodgers. 2001. Cumulating the intellectual gold of case study research. Public Administration Review 61:235-246. https://doi.org/10.1111/0033-3352.00025

Kaufmann-Hayoz, R., R. Defila, A. Di Giulio, and M. Winkelmann. 2016. Was man sich erhoffen darf - Zur gesellschaftlichen Wirkung transdisziplinärer Forschung. Pages 289-327 in R. Defila and A. Di Giulio, editors. Transdisziplinär forschen - zwischen Ideal und gelebter Praxis. Hotspots, Geschichten, Wirkungen. Campus Verlag, Frankfurt am Main, Germany.

Klenk, N. L., and K. Meehan. 2017. Transdisciplinary sustainability research beyond engagement models: toward adventures in relevance. Environmental Science \& Policy 78:27-35. https://doi.org/10.1016/j.envsci.2017.09.006

Lang, D. J., A. Wiek, M. Bergmann, M. Stauffacher, P. Martens, P. Moll, M. Swilling, and C. Thomas. 2012. Transdisciplinary research in sustainability science: practice, principles, and challenges. Sustainability Science 7:25-43. https://doi.org/10.1007/ s11625-011-0149-X

Leach, M., I. Scoones, and A. Stirling. 2010. Dynamic sustainabilities: technology, environment, social justice. Earthscan, London, UK. https://doi.org/10.4324/9781849775069

Levers, C., D. Müller, K. Erb, H. Haberl, M. R. Jepsen, M. J. Metzger, P. Meyfroidt, T. Plieninger, C. Plutzar, J. Stürck, P. H. Verburg, P. J. Verkerk, and T. Kuemmerle. 2018. Archetypical patterns and trajectories of land systems in Europe. Regional Environmental Change 18:715-732. https://doi.org/10.1007/ s10113-015-0907-x

Luederitz, C., N. Schäpke, A. Wiek, D. J. Lang, M. Bergmann, J. J. Bos, S. Burch, A. Davies, J. Evans, A. König, M. A. Farrelly, N. Forrest, N. Frantzeskaki, R. B. Gibson, B. Kay, D. Loorbach, K. McCormick, O. Parodi, F. Rauschmayer, U. Schneidewind, M. Stauffacher, F. Stelzer, G. Trencher, J. Venjakob, P. J. Vergragt, H. von Wehrden, and F. R. Westley. 2017. Learning through evaluation - a tentative evaluative scheme for sustainability transition experiments. Journal of Cleaner Production 169:61-76. https://doi.org/10.1016/j.jclepro.2016.09.005

Magliocca, N., T. K. Rudel, P. H. Verburg, W. J. McConnell, O. Mertz, K. Gerstner, A. Heinimann, and E. C. Ellis. 2015. Synthesis in land change science: methodological patterns, challenges, and guidelines. Regional Environmental Change 15:211-226. https://doi.org/10.1007/s10113-014-0626-8

Mauser, W., G. Klepper, M. Rice, B. S. Schmalzbauer, H. Hackmann, R. Leemans, and H. Moore. 2013. Transdisciplinary global change research: the co-creation of knowledge for sustainability. Current Opinion in Environmental Sustainability 5:420-431. https://doi.org/10.1016/j.cosust.2013.07.001

Miettinen, R., J. Tuunainen, and T. Esko. 2015. Epistemological, artefactual and interactional-institutional foundations of social impact of academic research. Minerva 53:257-277. https://doi. org/10.1007/s11024-015-9278-1 
Mitchell, C., D. Cordell, and D. Fam. 2015. Beginning at the end: the outcome spaces framework to guide purposive transdisciplinary research. Futures 65:86-96. https://doi. org/10.1016/j.futures.2014.10.007

Mog, J. M. 2006. Managing development programs for sustainability: integrating development and research through adaptive management. Society and Natural Resources 19:531-546. https://doi.org/10.1080/08941920600663961

Monzote, F. R. F., R. Bello, A. Alvarez, A. Hernández, E. A. Lantinga, and H. van Keulen. 2012. Identifying agroecological mixed farming strategies for local conditions in San Antonio de Los Baños, Cuba. International Journal of Agricultural Sustainability 10:208-229. https://doi.org/10.1080/14735903.2012.692955

Moser, S. C. 2016. Can science on transformation transform science? Lessons from co-design. Current Opinion in Environmental Sustainability 20:106-115. https://doi.org/10.1016/ j.cosust.2016.10.007

Muhonen, R., P. Benneworth, and J. Olmos-Peñuela. 2020. From productive interactions to impact pathways: understanding the key dimensions in developing SSH research societal impact. Research Evaluation 29(1):34-47. https://doi.org/10.1093/reseval/ $\underline{\text { rvz003 }}$

Newig, J., E. Challies, N. W. Jager, E. Kochskaemper, and A. Adzersen. 2018. The environmental performance of participatory and collaborative governance: a framework of causal mechanisms. Policy Studies Journal 46:269-297. https://doi. org/10.1111/psj.12209

Newig, J., S. Jahn, D. J. Lang, J. Kahle, and M. Bergmann. 2019. Linking modes of research to their scientific and societal outcomes. Evidence from 81 sustainability-oriented research projects. Environmental Science \& Policy 101:147-155. https://doi. org/10.1016/j.envsci.2019.08.008

Oberlack, C., T. Breu, M. Giger, N. Harari, K. Herweg, S. L. Mathez-Stiefel, P. Messerli, S. Moser, C. Ott, I. Providoli, T. Tribaldos, A. Zimmerman, and F. Schneider. 2019b. Theories of change in sustainability science: understanding how change happens. GAIA-Ecological Perspectives for Science and Society 28 (2):106-111. https://doi.org/10.14512/gaia.28.2.8

Oberlack, C., and K. Eisenack. 2018. Archetypical barriers to adapting water governance in river basins to climate change. Journal of Institutional Economics 14:527-555. https://doi. org/10.1017/S1744137417000509

Oberlack, C., D. Sietz, E. Bürgi Bonanomi, A. de Bremond, J. Dell'Angelo, K. Eisenack, E. Ellis, G. Epstein, M. Giger, A. Heinimann, C. Kimmich, M. T. J. Kok, D. Manuel-Navarrete, P. Messerli, P. Meyfroidt, T. Václavík, and S. Villamayor-Tomas. 2019a. Archetype analysis in sustainability research: meanings, motivations, and evidence-based policy making. Ecology and Society 24(2):26. https://doi.org/10.5751/ES-10747-240226

Oberlack, C., L. Tejada, P. Messerli, S. Rist, and M. Giger. 2016. Sustainable livelihoods in the global land rush? Archetypes of livelihood vulnerability and sustainability potentials. Global Environmental Change 41:153-171. https://doi.org/10.1016/j. gloenvcha.2016.10.001
Oettlé, N., A. Arendse, B. Koelle, and A. Van Der Poll. 2004. Community exchange and training in the Suid Bokkeveld: a UNCCD pilot project to enhance livelihoods and natural resource management. Environmental Monitoring and Assessment 99:115-125. https://doi.org/10.1007/s10661-004-4011-9

Ostrom, E. 2005. Understanding institutional diversity. Princeton University Press, New Jersey, Princeton, USA.

Ostrom, E. 2009. A general framework for analyzing sustainability of social-ecological systems. Science 325 (5939):419-422. https://doi.org/10.1126/science.1172133

Pahl-Wostl, C. 2002. Participative and stakeholder-based policy design, evaluation and modeling processes. Integrated Assessment 3:3-14. https://doi.org/10.1076/iaij.3.1.3.7409

Pahl-Wostl, C., J. Sendzimir, P. Jeffrey, J. Aerts, G. Berkamp, and K. Cross. 2007. Managing change toward adaptive water management through social learning. Ecology and Society 12 (2):30. https://doi.org/10.5751/ES-02147-120230

Pielke, R. A. 2014. The honest broker: making sense of science in policy and politics. 10th edition. Cambridge University Press, Cambridge, UK.

Pohl, C., and G. Hirsch Hadorn. 2007. Principles for designing transdisciplinary research. Swiss Academies of Arts and Sciences, Bern, Switzerland.

Pohl, C., and G. Hirsch Hadorn. 2008. Methodological challenges of transdisciplinary research. Natures Sciences Sociétés 16:111-121. https://doi.org/10.1051/nss:2008035

Pohl, C., S. Rist, A. Zimmermann, P. Fry, G. S. Gurung, F. Schneider, C. Ifejika Speranza, B. Kiteme, S. Boillat, E. Serrano, G. Hirsch Hadorn, and U. Wiesmann. 2010. Researchers' roles in knowledge co-production: experience from sustainability research in Kenya, Switzerland, Bolivia and Nepal. Science and Public Policy 37:267-281. https://doi.org/10.3152/030234210X496628

Polk, M. 2014. Achieving the promise of transdisciplinarity: a critical exploration of the relationship between transdisciplinary research and societal problem solving. Sustainability Science 9 (4):439-451. https://doi.org/10.1007/s11625-014-0247-7

Polk, M. 2015. Transdisciplinary co-production: designing and testing a transdisciplinary research framework for societal problem solving. Futures 65:110-122. https://doi.org/10.1016/j. futures.2014.11.001

Proclim/CASS Forum for Climate and Global Change/ Conference of the Swiss Scientific Academies. 1997. Visions by Swiss researchers: research on sustainability and global changevisions in science policy by Swiss researchers. ProClim, Bern, Switzerland.

Reed, M. S. 2008. Stakeholder participation for environmental management: a literature review. Biological Conservation 141:2417-2431. https://doi.org/10.1016/j.biocon.2008.07.014

Rudel, T. K. 2008. Meta-analyses of case studies: a method for studying regional and global environmental change. Global Environmental Change 18:18-25. https://doi.org/10.1016/j. gloenvcha.2007.06.001 
Schäfer, M., A. Lux, and M. Bergmann. 2020. Editorial to the special issue "Transdisciplinary Sustainability ResearchLinking research processes and outputs to societal effects." Environmental Science and Policy 107:206-210. https://doi. org/10.1016/j.envsci.2020.02.018

Schneider, F., and T. Buser. 2018. Promising degrees of stakeholder interaction in research for sustainable development. Sustainability Science 13:129-142. https://doi.org/10.1007/ $\underline{\text { s11625-017-0507-4 }}$

Schneider, F., P. Fry, T. Ledermann, and S. Rist. 2009. Social learning processes in Swiss soil protection - the 'from farmer to farmer' project. Human Ecology 37:475-489. https://doi. org/10.1007/s10745-009-9262-1

Selener, D. 1997. Participatory action research and social change. Second edition. Cornell University, Ithaca, New York, USA.

Sietz, D. 2017. Nested archetypes of vulnerability in African drylands. Environmental Research Letters 12(9).

Sietz, D., U. Frey, M. Roggero, Y. Gong, N. Magliocca, R. Tan, P. Janssen, and T. Václavík. 2019. Archetype analysis in sustainability research: methodological portfolio and analytical frontiers. Ecology and Society 24(3):34. https://doi.org/10.5751/ es-11103-240334

Sietz, D., M. K. B. Lüdeke, and C. Walther. 2011. Categorisation of typical vulnerability patterns in global drylands. Global Environmental Change 21:431-440. https://doi.org/10.1016/j. gloenvcha.2010.11.005

Soste, L., Q. J. Wang, D. Robertson, R. Chaffe, S. Handley, and Y. Wei. 2015. Engendering stakeholder ownership in scenario planning. Technological Forecasting and Social Change 91:250-263. https://doi.org/10.1016/j.techfore.2014.03.002

Termeer, C. J. A. M., A. Dewulf, G. Breeman, and S. J. Stiller. 2013. Governance capabilities for dealing wisely with wicked problems. Administration \& Society 47:680-710. https://doi. org/10.1177/0095399712469195

Termeer, C. J. A. M., and B. Kessener. 2007. Revitalizing stagnated policy processes: using the configuration approach for research and interventions. Journal of Applied Behavioral Science 43:256-272. https://doi.org/10.1177/0021886306294902

Václavík, T., F. Langerwisch, M. Cotter, J. Fick, I. Häuser, S. Hotes, J. Kamp, J. Settele, J. H. Spangenberg, and R. Seppelt. 2016. Investigating potential transferability of place-based research in land system science. Environmental Research Letters 11:9. https://doi.org/10.1088/1748-9326/11/9/095002

van Vliet, J., N. R. Magliocca, B. Büchner, E. Cook, J. M. Rey Benayas, E. C. Ellis, A. Heinimann, E. Keys, T. M. Lee, J. Liu, O. Mertz, P. Meyfroidt, M. Moritz, C. Poeplau, B. E. Robinson, R. Seppelt, K. C. Seto, and P. H. Verburg. 2016. Meta-studies in land use science: current coverage and prospects. Ambio 45:15-28. https://doi.org/10.1007/s13280-015-0699-8

Walter, A. I., S. Helgenberger, A. Wiek, and R. W. Scholz. 2007. Measuring societal effects of transdisciplinary research projects: design and application of an evaluation method. Evaluation and Program Planning 30(4):325-338. https://doi.org/10.1016/j. evalprogplan.2007.08.002
Wiek, A., S. Talwar, M. O'Shea, and J. Robinson. 2014. Toward a methodological scheme for capturing societal effects of participatory sustainability research. Research Evaluation 23:117-132. https://doi.org/10.1093/reseval/rvt031

Wright, S. 2014. Quantitative research performing other worlds: lessons from sustainable agriculture in the Philippines. Australian Geographer 45:1-18. https://doi.org/10.1080/00049182.2014.869293

Zscheischler, J., S. Rogga, and A. Lange. 2018. The success of transdisciplinary research for sustainable land use: individual perceptions and assessments. Sustainability Science 13:1061-1074. https://doi.org/10.1007/s11625-018-0556-3 
ABANG, M. M., BAYAA, B., ABU-IRMAILEH, B. \& YAHYAOUI, A. 2007. A participatory farming system approach for sustainable broomrape (Orobanche spp.) management in the Near East and North Africa. Crop Protection, 26, 1723-1732.

AKPO, E., CRANE, T. A., VISSOH, P. V. \& TOSSOU, R. C. 2015. Co-production of Knowledge in Multistakeholder Processes: Analyzing Joint Experimentation as Social Learning. Journal of Agricultural Education \& Extension, 21, 369-388.

ALLAN, C., NGUYEN, T. P. L., SEDDAIU, G., WILSON, B. \& ROGGERO, P. P. 2013. Integrating local knowledge with experimental research: Case studies on managing cropping systems in Italy and Australia. Italian Journal of Agronomy, 8, 108-116.

ANDERSSON, E. 2015. Turning waste into value: Using human urine to enrich soils for sustainable food production in Uganda. Journal of Cleaner Production, 96, 290-298.

BAGSHAW, J. \& LINDSAY, S. 2009. Developing Sustainable Banana Production Systems: a Case Study from Tropical Australia. In: OPPENHEIM, P. P. (ed.) Xvi International Symposium on Horticultural Economics and Management.

BINDER, C. R., SCHMID, A. \& STEINBERGER, J. K. 2012. Sustainability solution space of the Swiss milk value added chain. Ecological Economics, 83, 210-220.

BREU, T., MASELLI, D. \& HURNI, H. 2005. Knowledge for sustainable development in the Tajik Pamir Mountains. Mountain Research and Development, 25, 139-146.

BUTLER, L. M. \& MAZUR, R. E. 2007. Principles and processes for enhancing sustainable rural livelihoods: Collaborative learning in Uganda. International Journal of Sustainable Development and World Ecology, 14, 604-617.

CABRERA, V. E., BREUER, N. E. \& HILDEBRAND, P. E. 2008. Participatory modeling in dairy farm systems: A method for building consensual environmental sustainability using seasonal climate forecasts. Climatic Change, 89, 395-409.

CARRUTHERS, G. \& TINNING, G. 2003. Where, and how, do monitoring and sustainability indicators fit into environmental management systems? Australian Journal of Experimental Agriculture, 43, 307-323.

DEDRICK, A. R., BAUTISTA, E., CLYMA, W., LEVINE, D. B. \& RISH, S. A. 2000. The management improvement program (MIP): A process for improving the performance of irrigated agriculture. Irrigation and Drainage Systems, 14, 5-39.

DODD, M. B., WEDDERBURN, M. E., PARMINTER, T. G., THORROLD, B. S. \& QUINN, J. M. 2008. Transformation toward agricultural sustainability in New Zealand hill country pastoral landscapes. Agricultural Systems, 98, 95-107.

GUZMÁN, G. I., LÓPEZ, D., ROMÁN, L. \& ALONSO, A. M. 2013. Participatory action research in agroecology: Building local organic food networks in Spain. Agroecology and Sustainable Food Systems, 37, 127-146.

JACOBI, J., SCHNEIDER, M., BOTTAZZI, P., PILLCO, M., CALIZAYA, P. \& RIST, S. 2015. Agroecosystem resilience and farmers' perceptions of climate change impacts on cocoa farms in Alto Beni, Bolivia. Renewable Agriculture and Food Systems, 30, 170-183.

LEVAIN, A., VERTÈS, F., RUIZ, L., DELABY, L., GASCUEL-ODOUX, C. \& BARBIER, M. 2015. 'I am an Intensive Guy': The Possibility and Conditions of Reconciliation Through the Ecological Intensification Framework. Environmental Management, 56, 1184-1198.

MINAE, S., BUNDERSON, W. T., KANYAMA-PHIRI, G. \& IZAC, A. M. 1998. Integrating agroforestry technologies as a natural resource management tool for smallholder farmers. In: BLUME, $H$. P., EGER, H., FLEISCHHAUER, E., HEBEL, A., REIJ, C. \& STEINER, K. G. (eds.) Towards Sustainable Land Use, Vols I \& li: Furthering Cooperation between People and Institutions.

MOG, J. M. 2006. Managing development programs for sustainability: Integrating development and research through adaptive management. Society and Natural Resources, 19, 531-546.

MONZOTE, F. R. F., BELLO, R., ALVAREZ, A., HERNÁNDEZ, A., LANTINGA, E. A. \& VAN KEULEN, H. 2012. Identifying agroecological mixed farming strategies for local conditions in San Antonio de Los Baños, Cuba. International Journal of Agricultural Sustainability, 10, 208-229. 
OETTLÉ, N., ARENDSE, A., KOELLE, B. \& VAN DER POLL, A. 2004. Community exchange and training in the Suid Bokkeveld: A UNCCD pilot project to enhance livelihoods and natural resource management. Environmental Monitoring and Assessment, 99, 115-125.

RYSCHAWY, J., JOANNON, A., CHOISIS, J. P., GIBON, A. \& LE GAL, P. Y. 2014. Participative assessment of innovative technical scenarios for enhancing sustainability of French mixed crop-livestock farms. Agricultural Systems, 129, 1-8.

SCHWILCH, G., BACHMANN, F., VALENTE, S., COELHO, C., MOREIRA, J., LAOUINA, A., CHAKER, M., ADERGHAL, M., SANTOS, P. \& REED, M. S. 2012. A structured multi-stakeholder learning process for Sustainable Land Management. Journal of Environmental Management, 107, 5263.

SCHWILCH, G., LINIGER, H. P. \& HURNI, H. 2014. Sustainable Land Management (SLM) Practices in Drylands: How Do They Address Desertification Threats? Environmental Management, 54, 983-1004.

SOSTE, L., WANG, Q. J., ROBERTSON, D., CHAFFE, R., HANDLEY, S. \& WEI, Y. 2015. Engendering stakeholder ownership in scenario planning. Technological Forecasting and Social Change, 91, 250-263.

TERMEER, C. J. A. M. \& KESSENER, B. 2007. Revitalizing stagnated policy processes: Using the configuration approach for research and interventions. Journal of Applied Behavioral Science, 43, 256-272.

TISENKOPFS, T., KUNDA, I. \& ŠUMANE, S. 2014. Learning as Issue Framing in Agricultural Innovation Networks. Journal of Agricultural Education and Extension, 20, 309-326.

WRIGHT, S. 2014. Quantitative Research Performing other Worlds: Lessons from sustainable agriculture in the Philippines. Australian Geographer, 45, 1-18. 


\section{Appendix 2: Codebook}

This codebook compiles the attributes assigned to text sections in the primary case studies. Not all of these attributes are analysed in the paper because some yielded too little information for meaningful configurations. The codes with more digits denote sub-variables of codes with fewer digits, e.g. 1.2.1 is a sub-variable of 1.2 .

\section{Context conditions}

Context conditions include a variety of components that are important for describing a specific case. They refer to conditions of the researcher, the sustainability problem that the project is addressing, the degree of wickedness characterizing the case, actors and their context, the institutional background, the knowledge that is missing in the case, or power relations. In addition, we coded socalled situation changers that refer to unforeseen events with a high impact on the project.

\subsection{Research context}

This code refers to the researchers' contacts in the field. They are new if researchers get to know the societal actors at the start of the project, or they are firmly established if the researchers know the societal actors from previous projects or other contexts.

An example for a firmly established contact would be a follow-up project of a previous research project with the same societal actors.

\subsection{Sustainability problem}

This code describes problems for sustainability addressed in the project. They concern different dimensions such as resources and environment, the socio-economic environment, or governance questions.

\subsubsection{Resources and environment}

In resources and environment, we distinguish between competition, degradation, pollution and conflict. A competition problem takes places when different actors compete for the same scarce resource. This can lead to different situations such as advantages for more powerful resource users or degrading user habits due to overuse. An example for this situation is competition for water use in water scarce areas.

Degradation is coded when resources are overused. Examples are overgrazing of pasture land or increasing pest infestations due to unsustainable agricultural practices.

Pollution problems are coded when water quality is concerned. These problems concern too many nutrients from fertilizers or run-off from pesticides.

Conflicts between different resource users over resources are extreme cases of resource and environment problems. They range from low level (e.g., local disputes) to high-level conflicts (i.e., violence and armed conflict).

\subsubsection{Socio-economic}

Socio-economic sustainability problems concern societal issues and their economic implications. This code covers situations where the structure of a society or the structure of the economic system cause the problem. We distinguish between viability, markets, population pressure, poverty, gender and dependency. 
Economic viability concerns unsustainable economic settings such as businesses or other settings where the actors slowly degrade their assets base. Examples are declining margins and regular crop losses in specific agricultural sectors.

Markets problems refer to non- or ill-functioning markets. Examples are lacking markets to sell the products or poor market access due to remote locations.

Population pressure is coded when populations grow fast or when populations are large. These problems are often related to degradation problems.

Poverty is coded when populations are lacking the necessary means to sustain their daily lives or to make necessary investments. Examples include poverty after a job loss or insufficient margins for own produce.

Gender problems cover unequal access to land or other resources or decreasing crop production due to gender inequalities. Examples include women loosing their jobs first in economic crisis situations or women having unequal access to land.

Dependency problems are coded when people are dependent on outside support, which limits their own choices substantially. An example is the dependency on relief aid of international donors.

\subsubsection{Governance}

Governance problems involve the way in which resources or the society are governed. We distinguish between access, distribution and mismanagement.

Access is coded when people lack access to resources, social security systems, or other state services.

Distribution is coded when existing policies lead to uneven distribution of resources or poor infrastructure in certain areas.

Mismanagement problems are coded where the management of a system is inefficient and unnecessary losses occur. Examples are regulations that lead to low quality products, inadequate monitoring activities, or decaying infrastructure.

\subsection{Degree of wickedness}

Wicked problems are problems that cannot be solved (Rittel and Webber, 1973), because of complex interrelations where solving one aspect leads to problems elsewhere; connections over space and time render the outcome uncertain; and a high degree of normativity with conflicting values. We address these different dimensions of wicked problems through the sub-codes complexity (low vs. high), uncertainty (low vs. high), and conflicting values (consensus vs. conflict). Examples include problems within one sector vs. overlapping of different sectors and institutions (complexity); open unclear processes (uncertainty); or strong polarisation of actors' opinions on what is the right approach to address a specific problem (conflicting values).

\subsection{Missing knowledge}

In participatory research approaches, researchers often refer to different types of knowledge (CASS and ProClim, 1997), which include systems knowledge (how does a system function), target knowledge (what is a desirable state of a system), and transformation knowledge (how do we get to this desirable state). For an assessment of different participatory approaches, we code missing knowledge related to these knowledge types in the case studies. 
The codes cover situations where the functioning of a system is investigated (system knowledge); where a common goal or vision is sought (target knowledge); or a clear strategy for getting from one state to the other is necessary (transformation knowledge). Examples include investigation of climate change effects on farmers (system knowledge), the definition of best management practices (target knowledge), or how agricultural innovation networks can achieve more concerted actions (transformation knowledge).

\subsection{Actors}

This code informs about the involved actor groups, networks, familiarity, motivation and capacity of the involved actors, and the power constellation. The sub-code situation changers includes important events that change the course of the whole project but do not necessarily fit in one of the other categories.

\subsubsection{Network}

This sub-code informs about the way in which actors were connected before the project started. Familiar actors know each other but without having worked together before. New actors do not know each other at the start of the project and need to build all connections first. Well-established groups know each other from previous projects where they worked together before and trust is already built.

\subsubsection{Setting}

The research setting refers to the group constellations. Multi-actor groups bring together actors from different sectors and backgrounds. Single-actor groups bring together people from the same actor, organisation or background such as farmers, extension workers, government administration, soil scientists and seed producers.

\subsubsection{Level}

The level of actors includes the sub-codes sector, organisation or individuals.

Examples include different actors in the oil palm seedling supply system (sector); a group of civil servants from a Dutch ministry (organisational); or different actors from a community such as landowners, landless, men, women, children (individuals).

\subsubsection{Motivation}

Motivation informs about who initiated a project. Bottom-up initiatives are initiated by societal actors, top-down initiatives are launched by governmental actors or agencies, and research initiatives are started by researchers.

Examples include communities that address researchers to help them promoting their agricultural products (bottom-up); action plans to fight pest infestations in whole countries (top-down); or the desire to test the effectiveness of new management models (research).

\subsubsection{Actor capacity}

Capacity defines the availability of time and social competence among actors. We distinguish between knowledge, lack of knowledge, time, lack of time, social competence, lack of social competence.

Examples include important knowledge contribution by indigenous groups or the lack of adequate scientific knowledge (knowledge); the tight schedule of farmers during crop season (lack of time); behaviour that excludes certain actors from a group (lack of social competence). 


\subsubsection{Power}

We refer to Avelino and Wittmayer (2016) and their classification for coding power constellations. This includes one-sided dependence ( $A$ depends on $B$ but $B$ does not depend on $A=>B$ has power over $A$ ), mutual dependence ( $A$ depends on $B$ and $B$ depends on $A \Rightarrow A$ and $B$ have power over each other), independence ( $A$ and $B$ do not depend on each other $\Rightarrow>A$ and $B$ have no power over each other), cooperation ( $A$ exercises more power than $B$, but $A$ and $B$ have similar, collective goals), competition ( $A$ exercises more power than $B$, while $A$ and $B$ have mutually exclusive goals), and co-existence ( $A$ exercises more power than $B, A$ and $B$ have independent co-existent goals).

There were hardly any codings for this code.

\section{Sustainability impact goal}

The sustainability goal varies from case to case and takes different forms depending on what the aims of a project are. Often, projects have different interlinked sustainability goals. The categorisation of sustainability impact goals refers to Mitchells outcome space framework ((Mitchell et al., 2015).

\subsection{Knowledge products}

According to Mitchell et al. (2015), knowledge products contribute to knowledge stocks and flows, hence they are specific products that build parts of a knowledge system. We distinguish between decision-making tools, knowledge databases, action plans, scientific publications and non-academic publications.

\subsubsection{Decision-making tool}

Decision-making tools are support tools that help actors to take decisions in specific situations. An example is a whole farm simulation tool to tailor dairy farm adaptive management strategies for different climate conditions to decrease environmental impacts.

\subsubsection{Knowledge database}

Knowledge databases collect information within a specific thematic or methodological area.

\subsubsection{Action plans}

Action plans are strategies that explain how specific goals will be achieved within a certain timespan. An example is a project with a group of farmers to identify and develop potential solutions to soil productivity problems.

\subsubsection{Scientific publications}

Publications in peer-reviewed scientific journals.

\subsubsection{Non-academic publications}

Publications in non-scientific knowledge dissemination such as reports, newspaper articles, television programmes, etc.

\subsection{Learning}

The sub-code learning includes everything that refers to learning in the broad sense such as individual or group learning. We distinguish between development of ownership, new knowledge, networking, reflection on learning, trust building, self-confidence, capacity building and communicating best practices. 


\subsubsection{Development of ownership}

Through the participation in a project, the actors develop a feeling of being part of the project and having ownership of the project's impact. Examples include cases where the involved actors take over responsibility of the project's impact and carry on with it or further develop it after the project ends.

\subsubsection{New knowledge}

Different types of new knowledge on different topics are produced during a project.

\subsubsection{Networking}

This includes activities that intend to build new connections or establish relationships between the projects and other actors. An example is to link networks from previous projects to the actors in a new project.

\subsubsection{Reflection on learning}

Reflection on learning includes activities and exercises within a group to reflect on the performance of the group and to think about improvements in the groups processes. An example is the gathering of organic cooperatives and certifiers to think about the role, they can play in building resilience to climate change.

\subsubsection{Trust building}

Trust building includes activities that bring the different actors closer together and make them develop trust towards each other.

\subsubsection{Self-confidence}

This sub-code includes processes that strengthen actors' confidence that they are able to carry out or have the capacity to fulfil certain activities.

\subsubsection{Capacity building}

This includes processes to improve the capacity of actors in order to do their work. Examples are familiarising actors with processes and procedures, support actors in determining their preferences, or professionalising a problem solving approach and promote it to other actors.

\subsubsection{Communicating best practices}

This includes showing and communicating best management practices to a broader community. An example is the communication of recommendations for a more sustainable milk value chain.

\subsection{Real world transformations}

The categories in real world transformations refer to the classification by Gibson et al. (2005). They seem more suitable for our analysis than more classical distinctions between social, ecological and economic criteria because sustainability problems usually involve more than one of these three areas and are difficult to separate. Gibson's classification rather defines problem areas.

\subsubsection{Social-ecological integrity}

Social-ecological integrity codes goals that preserve the interrelations of social and biophysical systems and therefore, a key component of human wellbeing. It not only involves human impacts on the environment but also considers all the components of these systems such as social, ecological, 
economic, political as well as cultural aspects. An example are best practices for sustainable banana production that do not come with restricting regulations or administrative burdens.

\subsubsection{Enhanced livelihoods}

Enhanced livelihoods address the needs of people and communities. It entails different levels of needs depending on societies and cultures. Gibson et al. (2005) refer to sufficiency and opportunity when defining enhanced livelihoods, and distinguish between things that are necessary for survival and things that are necessary to live a fulfilled and meaningful life. An example is better marketing of rooibos production coupled with community-based tourism, which provides new attractive jobs and better incomes for the community.

\subsubsection{Intra- and intergeneration equity}

Intra- and intergenerational equity entails in the first place material equity. However, this does not suffice as material equity is closely related to political power and the possibility to participate in decision-making processes. In addition, the context in which people are born often influence their development in life and lead to a certain path-dependency for their children as well. Besides pathdependency in people's lives, the question of sufficiency and opportunity extends into the future for generations to come. Negotiating needs and values for future generations is an intractable task and yet needs to be included in the discussion on sustainability.

\subsubsection{Resource maintenance and efficiency}

Resource maintenance and efficiency is an important requirement for sustainable development because it leads a way to a more careful use of resources. Although it will not be sufficient for solving sustainability problems in general, it must play an important part in the transformation from current to more sustainable lifestyles. An example is high crop production while decreasing water pollution and minimising production costs.

\subsubsection{Social-ecological stewardship and democratic governance}

Social-ecological stewardship and democratic governance combines four different dimensions which often tend to be analysed in isolation. These include government, markets, custom and choice. In sustainable development, however, it is most often not possible to separate them. The requirement is based on transparency and participatory processes. An example is a sustainable community organising effort around natural resource management based on broad-based participation, cost sharing, and comanagement.

\subsubsection{Precaution and adaptation}

Risk, uncertainty and complexity in sustainability problems require precaution and adaptation in their search for solutions because it will never be possible to anticipate everything that will happen. This sub-code involves efforts to deal with unexpected consequences and effects that evolve with the solutions. Learning should be an inherent component thereof in order to make adaptation during processes possible. An example is the selecting, testing, and upscaling sustainable land management strategies to mitigate desertification.

\section{Participatory approach and methods}

This part describes what research approaches and methods are chosen, how different actors are involved in the process, and what roles they play.

\subsection{Participant roles}


Researchers and societal actors can take different roles in participatory research. We refer to work by Pielke (2014) for defining these sub-codes.

\subsubsection{Societal actors}

For the roles of societal actors, we distinguish between facilitating a participatory process, actively engaging in a process as knowledge producer, taking a more observing part as stakeholder, or being an expert who can give detailed input on a specific topic. These different roles also imply different understandings of the actors' contributions.

\subsubsection{Scientific actors}

The same is valid for scientific actors. Their contributions and responsibilities change depending on their roles as facilitators who organise reflexion processes, knowledge producers (which is the classical role of researchers), or experts who are invited to give their expertise in specific moments.

\subsection{Research process}

Our definition of research phases in participatory research are based on the work by Lang et al (2012). They introduce a set of design principles for an ideal transdisciplinary research process and differentiate three phases in the process, namely the framing of problems and the establishment of a research team, collaborative research and the co-production of knowledge, and the integration of new knowledge into societal and scientific practice.

\subsubsection{Research phase 1: problem framing and research team}

Activities in this sub-code include building a collaborative team, the joint problem identification and definition, jointly defining objectives and questions, assigning and supporting roles for actors, and agreeing on methodology for co-production and integration.

Examples include recruiting an interdisciplinary team to carry out different aspects of a project, the discussion of farmers' most relevant problems, the definition of objectives for a joint vision in 2025, establishing a facilitation team to organise exchange visits, or discussing and defining the individual steps and procedures of a project.

\subsubsection{Research phase 2: collaborative research and co-production of knowledge}

Activities within this sub-code include the integration of different methods, the adjustment of methods when necessary, the integration of different types of knowledge, and the mitigation of conflict when it occurs.

Examples include methods to integrate different learning episodes over time and space, the commitment to set an open agenda flexible for changes, the consideration of knowledge from different actors in the joint knowledge production, or the mitigation between conflicting groups within a project.

\subsubsection{Research phase 3: integrating new knowledge into science and societal practice}

This sub-code includes the integration of knowledge into science, the integration of knowledge into societal practice, generating targeted products, and evaluating impact.

Examples include the adaptation of scientific documentation, which includes the results from societal knowledge, the testing of project results on the own farm, to make agroecological management alternatives visible through local food markets or radio programmes, or to enquire actor's experiences in different study sites. 


\subsubsection{Intensity of actor interaction}

This sub-code includes intensities of actor interactions, i.e. information, consultation and coproduction in all three research phases. We code different activities that either inform actors about the project, its achievements or planned activities; consult actors about their wishes, concerns, expectations or preferences; or co-produce new knowledge in a joint effort where all involved actors contribute to the process with knowledge, expertise, time, etc.

Examples include first oral presentations and handing out of flyers, semi-structured interviews or questionnaires, or intense participatory knowledge production workshops with different actors.

\section{Impact}

The impact categories learning, knowledge products and real world transformations correspond to the sustainability impact goals.

\section{Cited literature}

AVELINO, F. \& WITTMAYER, J. M. 2016. Shifting Power Relations in Sustainability Transitions: A Multiactor Perspective. Journal of Environmental Policy \& Planning, 18, 628-649.

CASS \& PROCLIM 1997. Research on Sustainability and Global Change - Visions in Science Policy by Swiss Researchers. CASS/SANW.

GIBSON, R. B. 2005. Sustainability assessment : criteria and processes, London : Earthscan.

MITCHELL, C., CORDELL, D. \& FAM, D. 2015. Beginning at the end: The outcome spaces framework to guide purposive transdisciplinary research. Futures, 65, 86-96.

PIELKE, R. A. 2014. The honest broker : making sense of science in policy and politics, Cambridge, Cambridge University Press.

RITTEL, H., W. J. \& WEBBER, M. M. 1973. Dilemmas in a General Theory of Planning. Policy Sciences, $4,155-169$. 
Appendix 3: Overview of all reported sustainability problems

\begin{tabular}{|c|c|c|c|}
\hline & \multicolumn{3}{|c|}{ Reported sustainability problems } \\
\hline & Resources and environment & Socio-economic & Governance \\
\hline 1998 Minae et al. & Low soil fertility & Diminishing and fragmented uneconomic farm holdings & \\
\hline 2000 Dedrick et al. & Lower yields and severe pest infestations & High water costs and low commodity prices & \\
\hline 2003 Carruther Tinning & & & $\begin{array}{l}\text { Failing adaptive management due to lack of data from } \\
\text { monitoring }\end{array}$ \\
\hline 2004 Oettle et al. & Land degradation from overgrazing & Poverty and poor market access & $\begin{array}{l}\text { Inadequate government services to community, } \\
\text { isolating and disadvantaging policies }\end{array}$ \\
\hline 2005 Breu et al. & $\begin{array}{l}\text { Resource degradation through overuse of a growing } \\
\text { population }\end{array}$ & $\begin{array}{l}\text { Dependent on external relief aid, growing inequalities } \\
\text { (espec. Gender) and impoverishment }\end{array}$ & $\begin{array}{l}\text { Decaying public infrastructure, insufficient energy- } \\
\text { supply, lack of technical equipment, deficiencies in } \\
\text { legislation and state administration }\end{array}$ \\
\hline 2007 Abang et al. & Yield losses through pest infestations & & \\
\hline 2007 Butler and Mazur & Resourced degradation & Poverty and poor market access & Difficult or non existent access to government services \\
\hline 2007 Termeer Kessener & & & $\begin{array}{l}\text { Path dependency and mismanagement in the } \\
\text { governance system }\end{array}$ \\
\hline 2008 Cabrera et al. & Nitrate pollution in groundwater & & \\
\hline 2008 Dodd et al. & $\begin{array}{l}\text { Water pollution from livestock, declining biodiversity, } \\
\text { soil degradation }\end{array}$ & $\begin{array}{l}\text { Pressure from international markets and unsustainable } \\
\text { price support }\end{array}$ & \\
\hline 2009 Bagshaw Lindsay & Water pollution from banana production & $\begin{array}{l}\text { Financial pressure through declining margins and } \\
\text { destruction through tropical cyclones }\end{array}$ & \\
\hline 2012 Monzote et al. & $\begin{array}{l}\text { Soil compaction and degradation through heavy } \\
\text { machinery and intense cultivation }\end{array}$ & $\begin{array}{l}\text { Deterioration of farm infrastructure and lack of finances } \\
\text { to invest in specialised production }\end{array}$ & $\begin{array}{l}\text { Highly specialized crop systems suffer from poor } \\
\text { management of natural resources, marginalisation of } \\
\text { small-scale farmers }\end{array}$ \\
\hline 2012 Schwilch et al. & Desertification & & \\
\hline 2013 a-Allan et al. & Nitrate pollution in groundwater & & \\
\hline 2013 b-Allan et al. & Declining soil productivity & & \\
\hline 2013 b-Guzman et al. & & No own agroindustry & $\begin{array}{l}\text { Structural changes with degrading agrarian institutions, } \\
\text { power concentration }\end{array}$ \\
\hline 2014 Schwilch et al. & Desertification & & \\
\hline 2014 Tisenkopfs et al. & Competition over land with biogas production & Rising land prices & Low market integration \\
\hline 2015 Akpo et al. & & & $\begin{array}{l}\text { Low seedling quality due to mismanagement of } \\
\text { producers }\end{array}$ \\
\hline
\end{tabular}




\begin{tabular}{|c|c|c|c|}
\hline 2015 Andersson & Soil degradation & $\begin{array}{l}\text { Gender inequalities in accessing land and other } \\
\text { productive resources }\end{array}$ & $\begin{array}{l}\text { Poor infrastructure, weak social security systems, low } \\
\text { credit availability, fluctuating food prices }\end{array}$ \\
\hline 2015 Jacobi et al. & $\begin{array}{l}\text { Soil degradation, loss of arable land, primary forest } \\
\text { and biodiversity due to monocultures }\end{array}$ & & \\
\hline 2015 Levain et al. & Water pollution from livestock & & \\
\hline 2015 Soste et al. & Drought and declining availability of irrigation water & & \\
\hline
\end{tabular}

